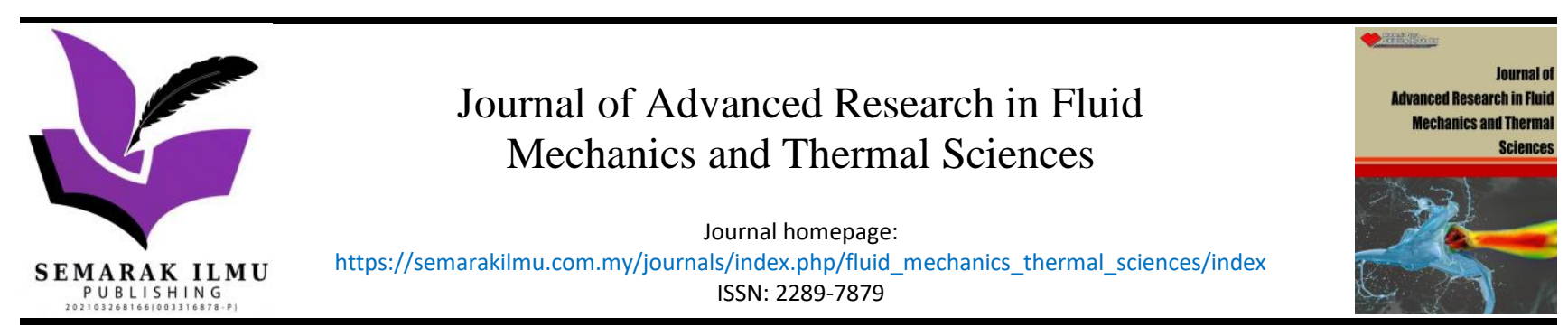

\title{
Refuse Derived Fuel for Energy Recovery by Thermal Processes. A Case Study in Depok City, Indonesia
}

\author{
Ariyanti Sarwono ${ }^{1}$, Iva Yenis Septiariva ${ }^{2}$, Fatimah Dinan Qonitan ${ }^{1}$, Nurulbaiti Listyendah Zahra ${ }^{1}$, \\ Mega Mutiara Sari ${ }^{1}$, Eva Nur Fauziah ${ }^{1}$, Novi Kartika Sari ${ }^{3}$, Kuntum Khoiro Ummatin ${ }^{4}$, Qurrotin \\ Ayunina Maulida Okta Arifianti ${ }^{4}$, Niswatun Faria ${ }^{4}$, Jun Wei Lim ${ }^{5}$, I Wayan Koko Suryawan ${ }^{1, *}$
}

1 Department of Environmental Engineering, Faculty of Infrastructure Planning, Universitas Pertamina, Komplek Universitas Pertamina, Jalan Sinabung II, Terusan Simprug, Jakarta 12220, Indonesia

2 Sanitary Engineering Laboratory, Study Program of Civil Engineering, Faculty of Engineering, Universitas Sebelas Maret, Jalan Ir Sutami 36A, Kentingan, Surakarta, Indonesia

3 Environmental Engineering Study Program, Jurusan Teknologi Infrastruktur dan Kewilayahan, Institut Teknologi Sumatera, Jl. Terusan Ryacudu, Way Huwi, Kec. Jati Agung, Kabupaten Lampung Selatan, Lampung 35365, Indonesia

4 Engineering Management, Industrial and Agroindusty Technology Faculty, Universitas Internasional Semen Indonesia, Kompleks PT. Semen Indonesia (Persero) Tbk, Jl. Veteran, Kb. Dalem, Sidomoro, Kebomas, Gresik 61122, East Java, Indonesia

5 Department of Fundamental and Applied Sciences, Faculty of Science and Information Technology, University Teknologi PETRONAS, Seri Iskandar 36210, Perak, Malaysia

\section{ARTICLE INFO}

\section{Article history:}

Received 11 April 2021

Received in revised form 28 August 2021

Accepted 9 September 2021

Available online 11 October 2021

\section{Keywords:}

Heating value; Waste to Energy; Thermal gravimetric analysis

\section{ABSTRACT}

The number of words should not exceed 350. Depok City is one of Indonesia's big cities, which is currently focused on processing waste-to-energy. This research was conducted to study and describe waste management in Depok City to become renewable energy. Secondary data from the Depok City local government's inventory was used to determine the generation and composition of municipal solid waste (MSW). The waste's characterization was taken from the material recovery facility of Depok City, located at Jalan Merdeka. The amount of waste generated in Depok City is predicted to reach 681.612 tons/year by 2025 . The significant waste composition items were food waste, garden waste, textiles, paper, and plastics. The result shows that the potential heating value for the waste was $35.04 \mathrm{MJ} / \mathrm{kg}$ Thermal gravimetric analysis (TGA) at a temperature range of $30-800^{\circ} \mathrm{C}$ showed only $1.39 \%$ leftover food, but mass decline at $30-110^{\circ} \mathrm{C}$ occurred quite slowly due to high air content. The optimum combustion temperature for paper, plastic, and garden waste are $317-430^{\circ} \mathrm{C}, 404.5-447.15^{\circ} \mathrm{C}$, and $251.78-479.9^{\circ} \mathrm{C}$, respectively. The total heating value obtained was equivalent to the electrical energy of 6635.2 GWh/year in 2025. A 1-tailed ANOVA analysis with a significance of $90 \%$ parameters of water content, carbon (C) composition, hydrogen composition $(\mathrm{H})$, and oxygen composition $(\mathrm{O})$ presented significances of $0.090 ; 0.005 ; 0.003$; and 0.037 , respectively.

\footnotetext{
* Corresponding author.

E-mail address: i.suryawan@universitaspertamina.ac.id
}

https://doi.org/10.37934/arfmts.88.1.1223 


\section{Introduction}

The waste management infrastructure in Depok City is managed at a temporary disposal site through an area-scale waste management unit as well as organic and inorganic waste treatment. Organic waste is used to be treated into compost, while inorganic waste can be processed into recycled products. However, composting treatment can produce leachate that gives environmental impact to the water body [1]. An integrated waste management concept combines environmentally friendly concepts with area-scale handling. This effort is significant to reduce the Cipayung Landfill, which has an increasingly limited land capacity [2]. Therefore, a breakthrough is needed to develop waste management technology through Waste to Energy (WtE) technology. Having good management in waste disposal leads the environment into more sustainable [3]. The maximizing the potential energy sources stored in waste using WtE concept can reduce waste disposal in the landfill. There have been numerous variations of WtE technology. The application of WtE in Indonesia is unfortunately still limited to the landfill gas utilization from landfill piles by an anaerobic process.

Previous research has provided the best scenario for processing 150 tons/day of Depok City waste by composting 80 tons/day and 500 tons/day by anaerobic digestion, and 390 tons/day by sending into a controlled landfill in Depok City [4]. Biological treatment of solid waste such as composting and anaerobic digester is still difficult to apply. The technologies, e.g., central composting, are often abandoned due to high operational and maintenance costs [5]. Good waste management in Indonesia can play an important role in promoting urban development's effectiveness with energy recovery to facilitate a sustainable national circular economy [6]. Recent findings also show landfill gas technology in several countries in Africa, such as Sudan, Uganda, Burundi, Tanzania, the Democratic Republic of the Congo, Chad, Guinea, Malawi, and Ethiopia, have negative net present value [7].

Depok City government constructed a recent alternative waste processing, namely the Temporary Waste Processing Site (TPSS) Merdeka 3, as a pilot project for the Refuse Derived Fuel (RDF) pellets. Several things to be needed attention from the potential of RDF as a waste to energy technology are the caloric value of RDF itself. There are two types of materials that contribute to the heating value of RDF directed to materials with high heating value a low heating value. However, the composition of waste in each region is very diverse, so it is necessary to know the waste material with the highest heating value applied in RDF raw material. In managing waste at Depok City, various problems and obstacles were faced, including the absence of a fair sales price agreement. The price problem is s major issue since the RDF selling price is pegged to coal's selling price, while coal's market price is very volatile. Apart from price, consideration of continuity and consistency of RDF supply and RDF calorie quality are critical considerations. The quality of RDF can be seen from the total calorie content, water content, and ash content of RDF, the content of various other minerals, and various other aspects. RDF needs to be encouraged by the Government, partly because RDF is a very environmentally friendly fuel and can also be called green coal. RDF comes from waste can help the Government deal with waste problems that have always been a source of problems in various regions.

RDF is a waste management technique by converting waste into something useful (fuel). The energy generated is calculated based on the calorific value/heat of the waste, so that the waste must be able to meet the minimum heat required to turn it into fuel or a heat source. Several previous studies, many potential waste materials have been carried out as raw materials for refuse derived fuel. In addition, it uses technology such as biodrying to reduce the water content of waste by utilizing the heat generated from the activity of microorganisms in degrading organic material so that there is an increase in heat. However, in this study, a more complete stage was carried out starting from 
calculating the amount of waste, doing the composition of the waste, to calculating qualitative analysis. Based on the description above, it is necessary to study municipal solid waste processing opportunities in Depok City as raw material for RDF. This study was conducted to determine waste generation, waste composition, and material flow for waste management at TPPS Depok City. After knowing the waste management, a quantitative analysis was carried out regarding the characteristics of waste as RDF raw material with proximate, ultimate, and heating value testing parameters.

\section{Methodology}

\subsection{Survey Location}

The survey was conducted to determine the existing waste management condition at TPPS Merdeka Depok (Figure 1). It aimed to determine its material flow analysis. The study location's scope is located at Sukmajaya District, Depok, Depok City, West Java. Secondary data collection was carried out in June 2020, where sampling was done in June - August 2020.

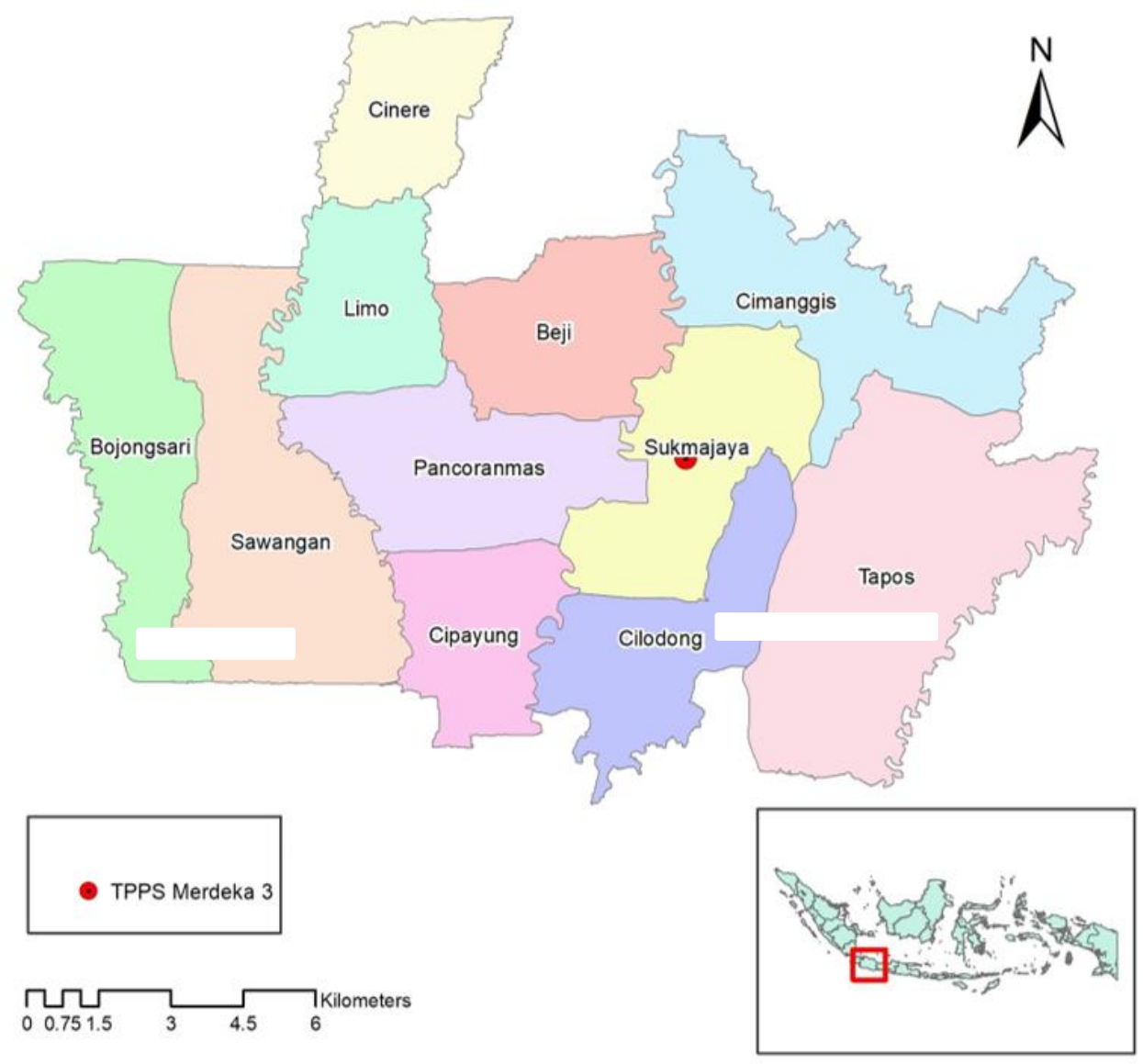

Fig. 1. Survey Location for Waste Sample Characteristic in Depok City

\subsection{Waste Generation and Composition in Depok City}

Waste sampling was conducted by indirect sampling, which was in line with the standard of waste generation measuring in the Indonesia National Standard as written in SNI 19-3964-1994 regarding obtaining and measuring waste generation and its composition. Those data were genuinely taken from the Environmental Service of Depok City. In contrast to developed countries, the amount of waste generation in the developing countries is generally obtained from the waste data record in 
landfills. There are some constraints as the scarcity of landfills equipped with truck scales and not all waste being transported to the landfills.

\subsection{Material Flow Analysis}

The flow of waste was analyzed for the input, output, and waste stock in the whole chain of waste management in Depok City. The calculation was performed by counting the waste in every chain of waste and subtracting unmanaged waste or waste illegally disposed to the environment-frequency of waste sale and the residue and handling through an in-depth interview with the facility officers. The officers are responsible for MSW management and is expected to provide information-rich and deeper comprehension of the circumstances [8].

\subsection{Measurement of Waste Characteristics}

The waste characteristics were measured by testing the moisture content and ash content for each waste material. The measurement followed to American Standard Testing and Materials (ASTM International) standard. The heating value is also measured by that standard using the bomb calorie metric. The calculated calorific value is the higher calorific value. The lower heat is only used as the basic minimum heat generated. The calorific value measured in the bomb calorimeter experiment is known as the High Heating Value (HHV), where the presence of water and hydrogen after combustion occurs is in a condensed state in the product. While Low Heating Value (LHV) is the heating value where it is assumed that water and hydrogen are in the vapor phase. The heat needed in the evaporation process is what will make the calorific value lower than the LHV. Calculation of the overall calorific value of waste is carried out by calculating the physical composition of the waste, multiplied by the calorific value data available from the experiment.

$H H V=P x H H V *$

where, $\quad \mathrm{HHV}=$ calorific value of waste components

$\mathrm{P} \quad$ = percentage of waste components (\% by weight)

$\mathrm{HHV}^{*}=$ calorific value data for each waste component from the bomb calorimeter experiment

Ultimate analysis was carried out to determine chemical elements contained in raw material. The ultimate test applied elemental analyzer test equipment. Thermal gravimetry analysis (TGA) was used to assess each category of waste's properties to be used as RDF for characterization purposes. TGA testing was done using a Mettler thermogravimetric analyzer in a range temperature of $30-800^{\circ} \mathrm{C}$ with a heating rate of $10^{\circ} \mathrm{C} /$ minute in a nitrogen gas environment. The materials used are only small pieces weighing a few milligrams of the selected waste sample.

\subsection{Calculation and Statistical Potential Heating Value}

The potential heating value of waste is used as a reference for waste that will be turned into RDF pellets. Waste with the most considerable potential heating value will be used as RDF pellets. The calculation was done to obtain a potential heating value [9]. Statistical analysis was also calculated to find the parameters most correlated with the increase in heating value. Moreover, correlation calculations were performed using SPSS 26 software. 


\section{Result and Discussion}

\subsection{Waste Generation and Composition in Depok City}

The projection of waste generation has been calculated about 681,612 tons/year by the Environmental Service of Depok City (Figure 2). The target of reducing waste in Depok City from $18 \%$ in 2018 to $30 \%$ in 2025 . To support the achievement of this waste reduction, Depok City has made an update on waste processing by building TPSS Merdeka 3 to recover waste energy. With the rapid increase in waste generation, the tonnage of combustible waste can support electricity production [10]. Based on the national waste management information system's data, the top five of Depok City's waste composition were food waste, garden waste, and plastic (Figure 3). As the seen waste generation with a low heating value from food waste, the waste has the potential to be adequately managed.

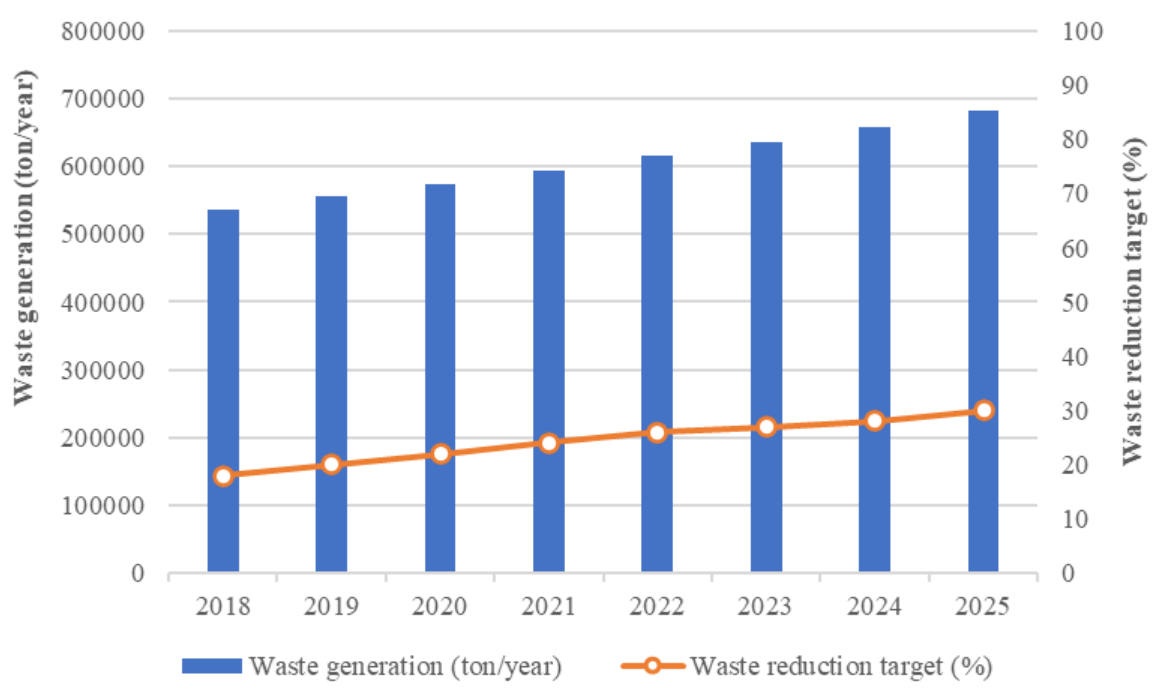

Fig. 2. Projection of waste generation and waste reduction targets in Depok City from 2018 - 2025 [11]

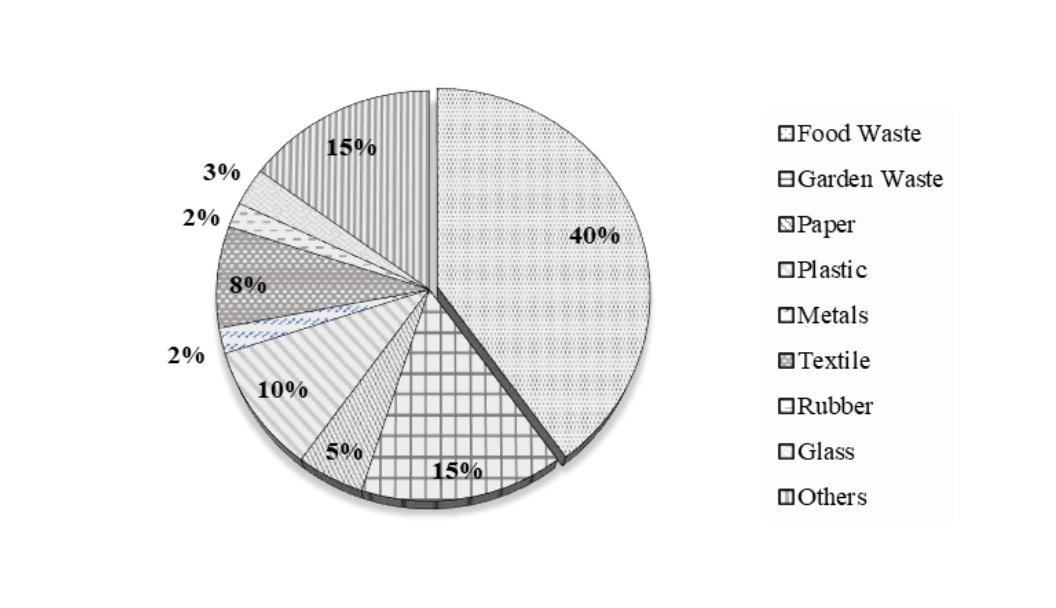

Fig. 3. Waste Composition in Depok City

Depok City consists of 11 subdistricts wherein each region has a different incidence (Figure 4). The highest rates of waste generation are in the Beji, Sukmajaya, and Cinere districts. The TPSS Merdeka 3 is applied to the Sumkajaya subdistrict. The Sukmajaya subdistrict also only produces $45 \%$ 
of the waste from the waste source [12]. Most people in Sukmajaya have actively participated in protecting the environment, such as disposing of waste in its place so that the surrounding environment remains clean and maintained [13]. This was a good sign to enhance environmental sustainability in which both of government and citizen have been integrated [8]. For this reason, the construction of TPSS Merdeka 3 can increase the positive potential in implementing the waste to energy program.

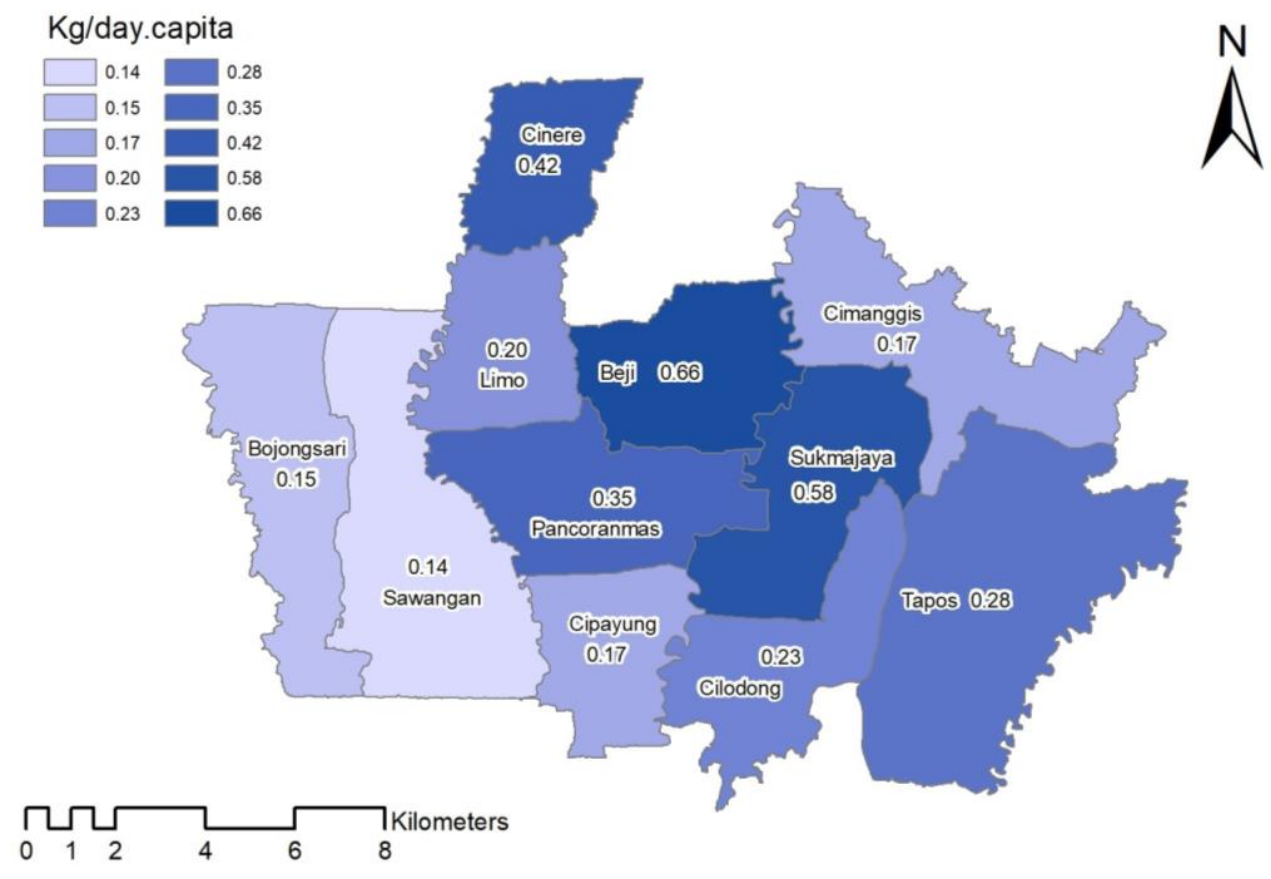

Fig. 4. The level of waste generation rate in each district of Depok City

\subsection{Material Flow Analysis in Depok City}

The construction of a Temporary Waste Processing Site (TPSS) in Depok City, located on Jalan Merdeka, Sukmajaya District, Depok City, was inaugurated in early March 2019. This TPSS is equipped with a sorting machine, a chopping machine, and a pellet-making machine as energy fuel with the ability to process up to 3 tons of waste per day. The construction of TPSS aims to improve access to proper sanitation, including solid waste for the community. This facility's provision is substantial to change people's perspective and behavior in seeing waste as a resource. In terms of its operation, TPSS Merdeka 3 only uses raw materials from garden waste. It has a $19.64 \mathrm{MJ} / \mathrm{kg}$ heating value. This value is still low compared to coal energy, which reaches $28.8 \mathrm{MJ} / \mathrm{kg}$ [14]. Converting municipal waste into RDF can be started by sorting waste, most of which is plastic [15]. Waste consisting of plastic and cellulose materials can be made into RDF after bio-drying and mechanical separation [16].

The material flow that is applied in TPSS Merdeka 3 Depok is depicted in Figure 5. Food waste can be turned into pellets after cutter and then mix it to other materials or adhesive. The cutter process does the paper, then the hammer mill process, and mixing with the adhesive. Meanwhile, the plastic chosen is PET plastic, which is then cuttings followed by a hummer mill process until mixing with adhesive. According to this scheme, it is expected that $61.5 \%$ of Depok city waste can be processed into RDF, while the remaining $38.5 \%$. The composition of plastic waste made from polyethylene terephthalate (PET) is based on many plastic bottles [17]. 


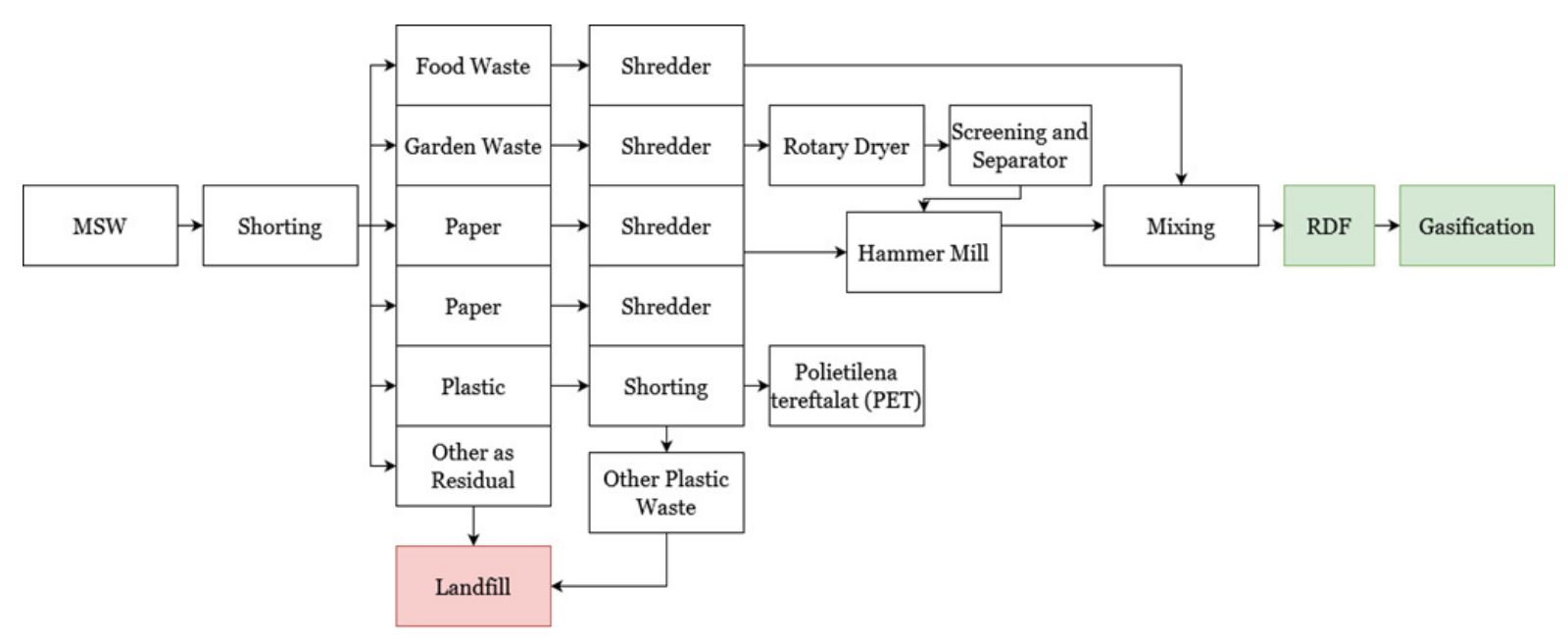

Fig. 5. Flow diagram of waste processing into RDF in Depok City

Figure 5 describes the stages of processing waste into RDF. Waste goes through several stages in its journey from waste to fuel. Pre-shredding brings the input material to a uniform size, which in some cases is already the correct size for the fuel, and removes excess that would interfere with further processing. Separation removes conflicting and recyclable materials from the fuel fraction. Fine crushing brings the fuel fraction, now free of contradictions, to the proper particle size. After filtering, ensure that the particles do not exceed the maximum size for fuel use.

\subsection{Waste Characteristics}

Table 1 shows the results of characterization for each composition of waste in Depok City. The ultimate analysis generally contains carbon, hydrogen, oxygen, other minerals elemental composition. The measured composition was water content (WC), ash content (AC), Carbon (C), Oxygen (O), Hydrogen $(\mathrm{H})$, oxygen $(\mathrm{O})$, and caloric value $(\mathrm{CV})$ (Table 1$)$. The highest water content value was found in food waste. Regarding its composition, food waste is very high but has a low heating value. For the use of waste with this composition, further processing is required, such as drying $[18,19]$.

Ash content indicates the number of minerals in the waste, and high ash content will also cause fly ash and bottom ash. The highest ash content in Depok City is plastic waste. Plastic waste in TPSS Merdeka 3 Depok strongly avoids using this category because of the possibility of contamination in the form of dioxins. Not all types of plastic can produce dioxin gas. Therefore, plastic waste must be seen from its type. Research states that the plastic kind of poly (vinyl chloride) (PVC) waste produces this dangerous gas [20].

\section{Table 1}

Depok City Waste Characterization Results based on Proximate, Ultimate, and Heating Value Analysis

\begin{tabular}{llllllll}
\hline Waste composition & $\begin{array}{l}\text { Water content } \\
(\%)\end{array}$ & $\begin{array}{l}\text { Ash content } \\
(\%)\end{array}$ & $\mathrm{C}(\%)$ & $\mathrm{H}(\%)$ & $\mathrm{N}(\%)$ & $\mathrm{O}(\%)$ & $\begin{array}{l}\text { Heating Value } \\
(\mathrm{MJ} / \mathrm{kg})\end{array}$ \\
\hline Paper & 11.32 & 6.00 & 35.22 & 6.67 & 0.00 & 44.75 & 13.88 \\
Plastic & 8.43 & 10.00 & 61.92 & 4.13 & 0.00 & 18.13 & 24.88 \\
Food Waste & 77.65 & 5.00 & 29.75 & 6.78 & 1.94 & 35.53 & 10.16 \\
Garden Waste & 11.65 & 6.30 & 41.64 & 4.85 & 1.47 & 36.84 & 19.64 \\
Textile & 11.70 & 4.30 & 33.31 & 6.61 & 1.00 & 30.50 & 12.56 \\
Rubber & 7.20 & 4.00 & 56.20 & 4.10 & 0.76 & 16.00 & 23.20 \\
\hline
\end{tabular}


The results of measuring the waste elements show the value of the carbon, hydrogen, nitrogen, and oxygen content in Depok City waste. The highest carbon content can reach $61.92 \%$, namely plastic waste, where this waste can also produce the highest heating value, namely $24.88 \mathrm{MJ} / \mathrm{kg}$. The combustible will depend on organic carbon content. The plastic content is usually found in crude oil and other raw material of fuel [9]. The nitrogen content in food waste and garden waste can reach $1.94 \%$ and $1.47 \%$. The nitrogen content cause concern as it could contribute to NOx emissions [21].

Figure 6 shows that each type of waste has a different thermal decomposition process. Plastic waste undergoes one-stage decomposition in the range of temperature of $300-500^{\circ} \mathrm{C}$. This temperature is quite good because it is not too high for the pyrolysis process. The polystyrene content in plastics can decompose at $500-550{ }^{\circ} \mathrm{C}$ [22]. The thermal gravimetric curve also states that plastic wrapping waste contains relatively small material that has not been decomposed until the end (residue) (-1.61\%). RDF briquettes are prepared in advance with the aim of increasing the density and reducing the water content.

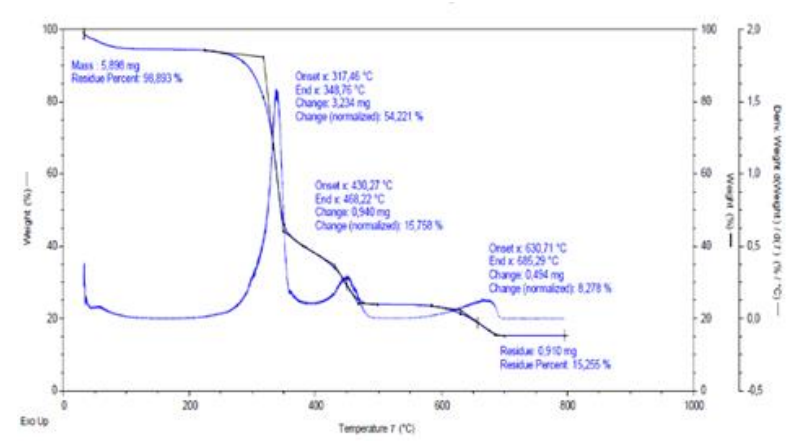

(a) Paper waste

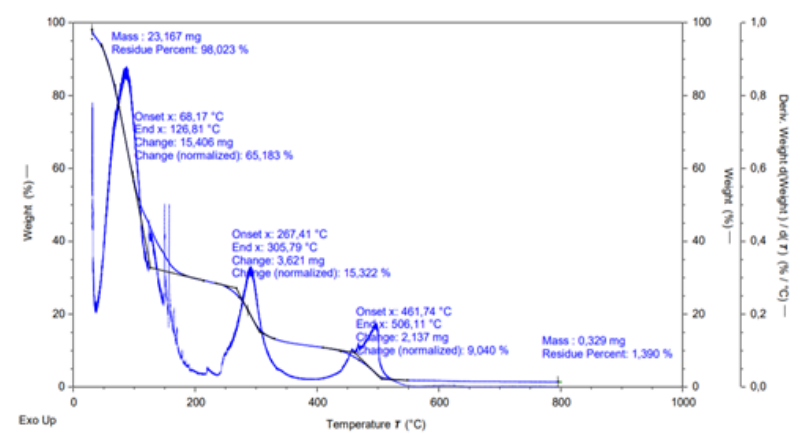

(c) Food Waste

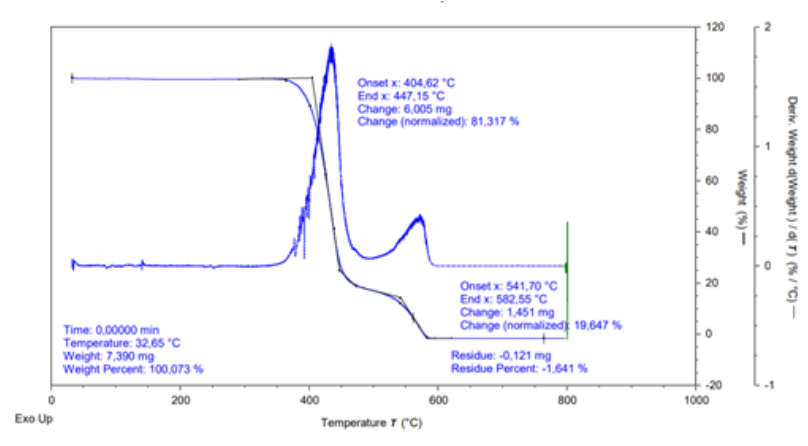

(b) Plastic

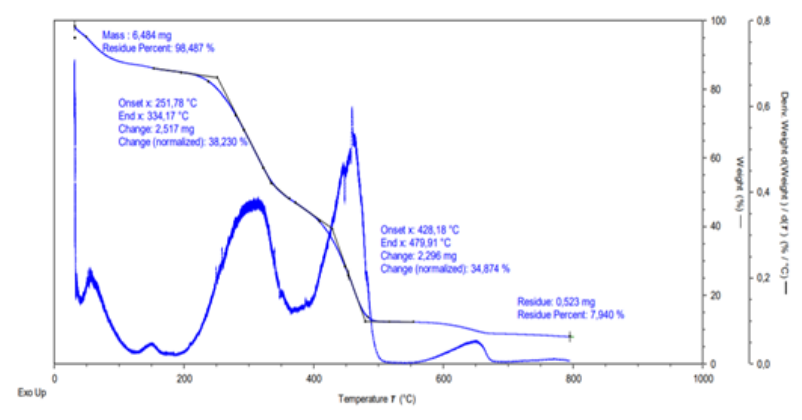

(d) Garden Waste

Fig. 6. Measurement of Thermal Gravimetry Analysis (TGA) for Waste in Depok City

The composition of paper, food waste, and garden waste consists of three main components, namely hemicellulose, cellulose, and lignin. Biomass will decrease if there is an increase in temperature because heat will decompose the biomass's chemical compound into gaseous compounds [23]. The decomposed biomass is divided into three stages depending on the composition of the sample. The first stage of the sample occurs mass loss due to the evaporation of water in the sample. The second stage is related to the devolatilization of hemicellulose, cellulose, and lignin compounds. The third stage relates to thermal stability, namely, the mass has begun to stabilize, or no more mass changes occur [24]. The lowest residue's TGA is food waste, which only has a residue of $1.39 \%$. The residues for paper waste and garden waste were $15.26 \%$ and $7.94 \%$, respectively. At a temperature of $0-110^{\circ} \mathrm{C}$, there is a very significant decrease in food waste. This is related to food waste with very high-water content, so that the graph on the TGA decreases very drastically (Figure 6c). Paper waste has a significant reduction in mass at temperatures of $317-430^{\circ} \mathrm{C}$. 
Plastic waste undergoes a mass difference of $81.32 \%$ at a temperature of $404.5-447.15^{\circ} \mathrm{C}$. Garden waste undergoes the slowest mass difference, which occurs gradually at a temperature of 251.78 $334.17^{\circ} \mathrm{C}$ and the second stage at a temperature of $428.18-479.9^{\circ} \mathrm{C}$.

\subsection{Potential Energy from Depok City Municipal Solid Waste}

The projection results of waste generation energy in 2025 (681,612 tons/year) produced in Depok City can reach 6,635.2 GWh/year (Figure 7). Using RDF, the processing waste results show a higher value than methane gas to become electricity of $548.59 \mathrm{GWh}$. Compared with the City of Jakarta's calculated potential can reach $48,571.3 \mathrm{kWh} /$ ton with a total of 253 tonnes of waste processed/day for electricity production of $12,288,529 \mathrm{kWh} /$ day to become RDF [21].

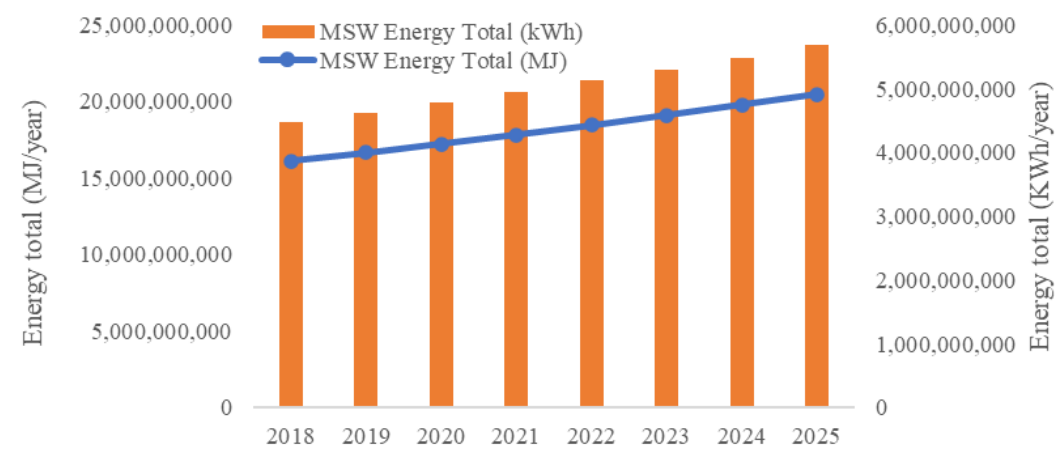

Fig. 7. Projection of Potential Energy Generated by Depok City from Municipal Solid Waste Generation

To get the same amount of electricity it is necessary to plan an excellent electric power generator. Boiler efficiency must be applied based on a waste boiler's typical price that operates with a conventional coal boiler system that can reach $85 \%$. [25]. The steam turbine's efficiency is based on the rank cycle's efficiency, ranging from 25-30\% [26]. Refuse Derived Fuel (RDF) is obtained from MSW remnants that cannot be used anymore, namely combustible waste and separated from noncombustible parts through chopping, sifting, and air classification processes. With this recycling effort, it can be beneficial in terms of reducing environmental impacts. Landfill which is currently operating in Depok City as open dumping and has exceeded its capacity can cause various environmental impacts. The environmental impact of landfills causes the effects of greenhouse gases and uncontrolled leachate $[27,28]$.

\subsection{Statistical Analysis}

The statistical analysis was done to find the effect among parameters of waste material in Depok City. These results can also be used as a reference in determining the characteristics of waste that can improve the quality of RDF, especially in determining the heating value. Table 2 shows the parameters that affect the heating value are the water content of carbon $(C)$, hydrogen $(H)$, and oxygen $(0)$ values at a 0.1 significance level.

Water content is the amount of water in a material, where the water content depends on the amount of hydrogen $(\mathrm{H})$ and oxygen $(\mathrm{O})(\mathrm{p}$-value $<0.1)$. The high-water content will cause a decrease in energy. The water content affects the heating value because when the water is burned, it will take the energy (expressed in terms of heat) contained in the evaporation system [29]. Furthermore, water content also affects fuel quality, such as heating value and burning time [30, 31, 32]. Carbon 
can produce combustion products in the form of carbon dioxide. The carbon value influences the heating value ( $p$-value: 0.005). The higher the carbon value, the higher the high heating value [33]. This means that in very dry conditions, the amount of carbon produced is even greater.

The correlation calculation can be seen in Figure 8. The water content parameters, hydrogen $(\mathrm{H})$ and oxygen $(\mathrm{O})$ have an inverse relationship with heating value in a range of $\mathrm{R} 2$, about $0.39-0.87$. This means that the higher the value of water, hydrogen $(\mathrm{H})$, and oxygen $(\mathrm{O})$ content, the lower the heating value. In contrast to the carbon (C) value, the higher the carbon composition, the higher the material's heating value $\left(\mathrm{R}^{2}=0.83\right)$. Based on Figure 8 , the correlation between $\mathrm{H}$ and $\mathrm{HV}$ gives the best result (0.87) rather than WC-HV, C-HV, and O-HV in a row.

\section{Table 2}

The results of 1-tailed ANOVA Statistics Calculation for Characterization of Waste Composition in Depok City

\begin{tabular}{llllllll}
\hline Sig. (1-tailed) & $\begin{array}{l}\text { Heating } \\
\text { Value }(\mathrm{HV})\end{array}$ & $\begin{array}{l}\text { Water } \\
\text { content } \\
(\mathrm{WC})\end{array}$ & $\begin{array}{l}\text { Ash } \\
\text { content } \\
(\mathrm{AC})\end{array}$ & $\begin{array}{l}\text { Carbon } \\
(\mathrm{C})\end{array}$ & $\begin{array}{l}\text { Hydrogen } \\
(\mathrm{H})\end{array}$ & $\begin{array}{l}\text { Nitrogen } \\
(\mathrm{N})\end{array}$ & $\begin{array}{l}\text { Oxygen } \\
(\mathrm{O})\end{array}$ \\
\hline Heating Value &. & 0.090 & 0.145 & 0.005 & 0.003 & 0.344 & 0.037 \\
Water content & 0.090 &. & 0.339 & 0.131 & 0.146 & 0.064 & 0.292 \\
Ash content & 0.145 & 0.339 &. & 0.131 & 0.202 & 0.150 & 0.357 \\
$\mathrm{C}$ & 0.005 & 0.131 & 0.131 &. & 0.003 & 0.138 & 0.021 \\
$\mathrm{H}$ & 0.003 & 0.146 & 0.202 & 0.003 &. & 0.292 & 0.037 \\
$\mathrm{~N}$ & 0.344 & 0.064 & 0.150 & 0.138 & 0.292 &. & 0.346 \\
$\mathrm{O}$ & 0.037 & 0.292 & 0.357 & 0.021 & 0.037 & 0.346 &. \\
\hline
\end{tabular}
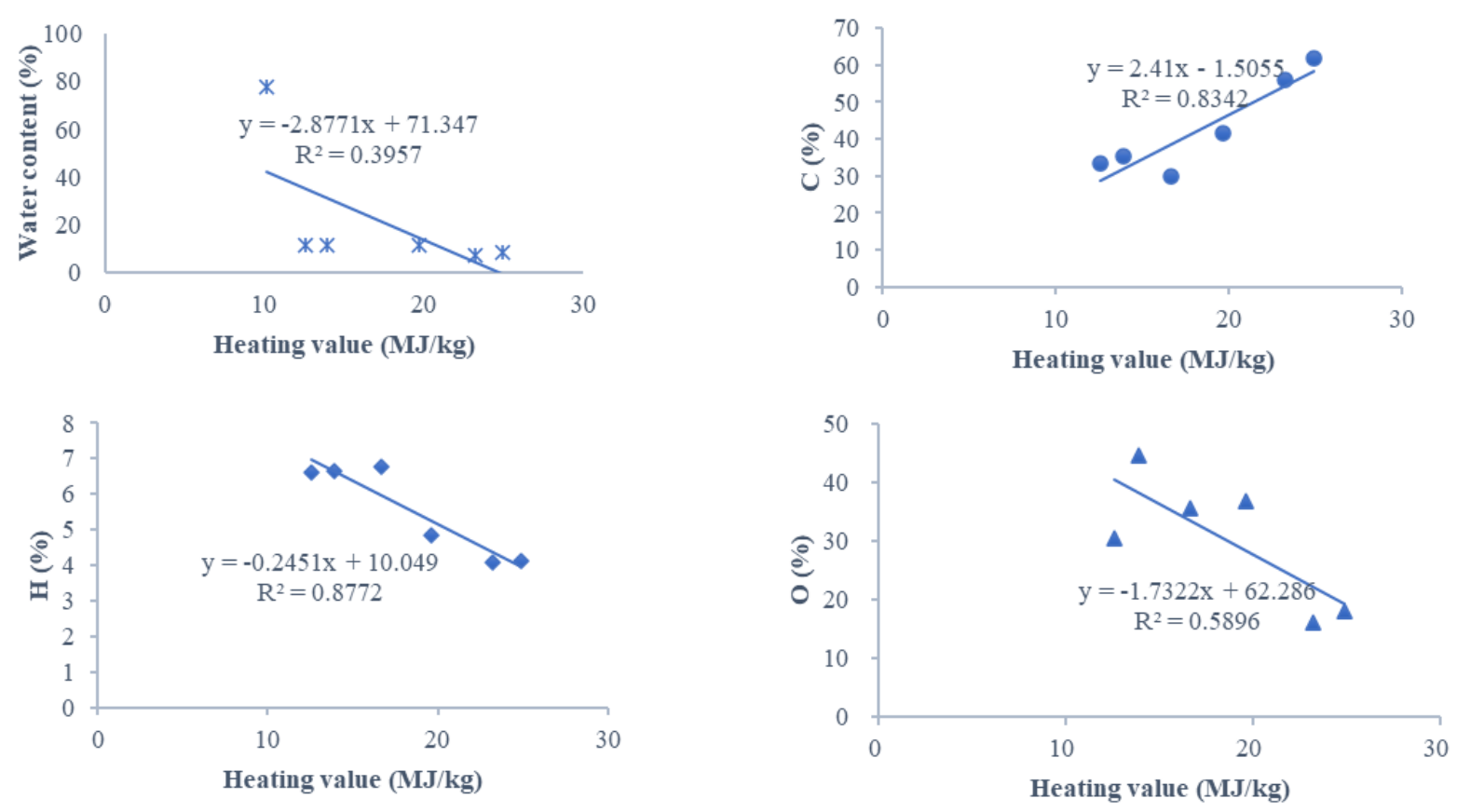

Fig. 8. Calculation of the Correlation of Composition of Parameters Associated with the Heating Value of Waste in Depok City

\section{Conclusion}

Based on the calculation results of waste generation and composition, it can be found that food waste, garden waste, plastic, and paper are waste that must be processed further. The results of waste characterization show that the highest heating value can be achieved due to plastic waste, 
namely $24.88 \mathrm{MJ} / \mathrm{kg}$ and food waste of $10.16 \mathrm{MJ} / \mathrm{kg}$. The food waste must be processed by pretreatment first to reduce the water content contained. If the utilization of all processed waste in Depok City can reach $6635.2 \mathrm{GWh} /$ year in 2025. The significant parameters in increasing the heating value are the carbon $(\mathrm{C})$ content, while the moisture, Hydrogen $(\mathrm{H})$, and Oxygen $(\mathrm{O})$ can reduce the heating value in waste material. The use of waste-derived fuels (RDF) is an integral part of currently regulated waste disposal. By using a selective treatment process, the calorific-worthy fraction, is separated from commercial and industrial waste, resulting in a marketable product.

\section{Acknowledgments}

The authors would like to thank you to the Depok City government. This research was also conducted as a preliminary research study in collaboration UP-UISI with contract number 359/UPWR3.1/PJN/VII/2020.

\section{References}

[1] Adriansyah, H. S., D. M. Hartono, N. Suwartha, and I. Gusniani. "The analysis of groundwater quality around a material (solid waste) recovery facility (a case study of the Merdeka 2 material recovery facility in Depok, West Java)." In IOP Conference Series: Materials Science and Engineering, vol. 536, no. 1, p. 012074. IOP Publishing, 2019. https://doi.org/10.1088/1757-899X/536/1/012074

[2] DISKOMINFO Kota Depok. "Analisis Strategi Kota Cerdaskota Depok." Depok: Dinas Kominfo Kota Depok, 2019.

[3] Noruzman, A. H. and Apandi, N. M. "Paint Waste Management in Industry." Journal of Advanced Research in Business and Management Studies 20, no. 1 (2020): 28-33. https://doi.org/10.37934/arbms.20.1.2833

[4] Kristanto, Gabriel Andari, and William Koven. "Estimating greenhouse gas emissions from municipal solid waste management in Depok, Indonesia." City and Environment Interactions 4 (2019): 100027. https://doi.org/10.1016/i.cacint.2020.100027

[5] Gebrezgabher, Solomie, Avinandan Taron, and Sena Amewu. "Nutrient recovery for use in agriculture: economic assessment of decentralized compost business model in Nairobi." In A Nexus Approach for Sustainable Development, pp. 25-38. Springer, Cham, 2021. https://doi.org/10.1007/978-3-030-57530-4 3

[6] Kurniawan, Tonni Agustiono, Ram Avtar, Deepak Singh, Wenchao Xue, Mohd Hafiz Dzarfan Othman, Goh Hui Hwang, Iswanto Iswanto, Ahmad B. Albadarin, and Axel Olaf Kern. "Reforming MSWM in Sukunan (Yogjakarta, Indonesia): A case-study of applying a zero-waste approach based on circular economy paradigm." Journal of cleaner production (2020): 124775. https://doi.org/10.1016/i.jclepro.2020.124775

[7] Cudjoe, Dan, and Myat Su Han. "Economic feasibility and environmental impact analysis of landfill gas to energy technology in African urban areas." Journal of Cleaner Production 284 (2021): 125437. https://doi.org/10.1016/i.jclepro.2020.125437

[8] Beleya, P., Ci, C. Xi., and Wen, C. L. "Challenges in Enhacing Solid Waste Management towards Sustainable Environment: Local Council Perspectives". Journal of Advanced Research in Business and Management Studies 16 (2019): 44-59. https://doi.org/10.37934/arbms.20.1.2833

[9] Tchobanoglous, G., Hn Theisen, and S. Vigil. "Integrated Solid Waste Management, Engineering Principles and Management Issues." Mc Graw-Hill Book Co, Singapore (1993).

[10] Akinshilo, Akinbowale. "Energy Potential from Municipal Solid Waste (MSW) for a Developing Metropolis." Journal of Thermal Engineering 5, no. 6 (2018): 196-204. https://doi.org/10.18186/thermal.654322

[11] Suryahati, E, "RENCANA PROGRAM KEGIATANBIDANG KEBERSIHAN TA.," BAPPEDA Kota Depok, Depok, 2019.

[12] Amri, S., TE B. Soesilo, and D. N. Martono. "Optimization of waste management in developing countries with spatial approaches (Study case: Depok City and Curitiba City)." In IOP Conference Series: Earth and Environmental Science, vol. 561, no. 1, p. 012021. IOP Publishing, 2020. https://doi.org/10.1088/1755-1315/561/1/012021

[13] Endangsih, Tri. "Evaluation of Environmental Performance Using the Green City Index in Depok City, Indonesia." In Journal of Physics: Conference Series, vol. 1625, no. 1, p. 012001. IOP Publishing, 2020. https://doi.org/10.1088/1742-6596/1625/1/012001

[14] Saqib, Najam UI, Ajit K. Sarmah, and Saeid Baroutian. "Effect of temperature on the fuel properties of food waste and coal blend treated under co-hydrothermal carbonization." Waste Management 89 (2019): 236-246. https://doi.org/10.1016/i.wasman.2019.04.005

[15] Khosasaeng, Trirat, and Ratchaphon Suntivarakorn. "Effect of equivalence ratio on an efficiency of single throat downdraft gasifier using RDF from municipal solid waste." Energy Procedia 138 (2017): 784-788. https://doi.org/10.1016/i.egypro.2017.10.066 
[16] Fei, Fan, Zongguo Wen, Shengbiao Huang, and Djavan De Clercq. "Mechanical biological treatment of municipal solid waste: Energy efficiency, environmental impact and economic feasibility analysis." Journal of Cleaner Production 178 (2018): 731-739. https://doi.org/10.1016/i.jclepro.2018.01.060

[17] Annisa, Bismi. "Asesmen Pemulihan Potensi Daur Ulang Material Sampah Perkotaan Di TPA Sampah." Jurnal Saintis 15, no. 2 (2015): 31-40.

[18] Ma, Jiao, Lei Zhang, Lan Mu, Kongyun Zhu, and Aimin Li. "Thermally assisted bio-drying of food waste: Synergistic enhancement and energetic evaluation." Waste Management $80 \quad$ (2018): $327-338$. https://doi.org/10.1016/i.wasman.2018.09.023

[19] Psaltis, Panagiotis, and Dimitrios Komilis. "Environmental and economic assessment of the use of biodrying before thermal treatment of municipal solid waste." Waste Management 83 (2019): 95-103. https://doi.org/10.1016/i.wasman.2018.11.007

[20] Liu, Yijie, Chuanbin Zhou, Feng Li, Hongju Liu, and Jianxin Yang. "Stocks and flows of polyvinyl chloride (PVC) in China: 1980-2050." Resources, $\quad$ Conservation and Recycling $154 \quad$ (2020): 104584. https://doi.org/10.1016/i.resconrec.2019.104584

[21] Zhao, Lei, Apostolos Giannis, Wan-Yee Lam, Sheng-Xuan Lin, Ke Yin, Guo-An Yuan, and Jing-Yuan Wang. "Characterization of Singapore RDF resources and analysis of their heating value." Sustainable Environment Research 26, no. 1 (2016): 51-54. https://doi.org/10.1016/j.serj.2015.09.003

[22] Kaminsky, W., B. Schlesselmann, and C. Simon. "Olefins from polyolefins and mixed plastics by pyrolysis." Journal of Analytical and Applied Pyrolysis 32 (1995): 19-27. https://doi.org/10.1016/0165-2370(94)00830-T

[23] Widyatmoko, H. "Refuse derived fuel potential in DKI Jakarta." In IOP Conference Series: Earth and Environmental Science, vol. 106, no. 1, p. 012099. IOP Publishing, 2018. https://doi.org/10.1088/1755-1315/106/1/012099

[24] Boumanchar, Imane, Younes Chhiti, Fatima Ezzahrae M’hamdi Alaoui, Amal El Ouinani, Abdelaziz Sahibed-Dine, Fouad Bentiss, Charafeddine Jama, and Mohammed Bensitel. "Effect of materials mixture on the higher heating value: Case of biomass, biochar and municipal solid waste." Waste management 61 (2017): 78-86. https://doi.org/10.1016/i.wasman.2016.11.012

[25] Young, Gary C. Municipal solid waste to energy conversion processes: economic, technical, and renewable comparisons. John Wiley \& Sons, 2010. https://doi.org/10.1002/9780470608616

[26] Monice, Monice, and Perinov Perinov. "Analisis Potensi Sampah sebagai Bahan Baku Pembangkit Listrik Tenaga Sampah (PLTSa) di Pekanbaru." SainETIn (Jurnal Sains, Energi, Teknologi \& Industri) 1, no. 1 (2016): 9-16. https://doi.org/10.31849/sainetin.v1i1.166

[27] Septiariva, Iva Yenis, \& Suryawan, I. "Development of water quality index (WQI) and hydrogen sulfide (H2S) for assessment around suwung landfill, Bali Island." Journal of Sustainability Science and Management (2021). 16 : 137148. http://doi.org/10.46754/issm.2021.06.0012

[28] Yodi, Yodi., Afifah, Anshah Silmi Estimation of Green House Gas (GHG) emission at Telaga Punggur landfill using triangular, LandGEM, and IPCC methods. In Journal of Physics: Conference Series, vol. 1456, no.1, p.012001. IOP Publishing, 2020. http://doi.org/10.1088/1742-6596/1456/1/012001

[29] Sukarta, I. Nyoman, and Putu Sri Ayuni. "Analisis Proksimat dan Nilai Kalor pada Pellet Biosolid yang Dikombinasikan Dengan Biomassa Limbah Bambu." JST (Jurnal Sains dan Teknologi) 5, no. 1 (2016). https://doi.org/10.23887/jstundiksha.v5i1.8278

[30] Hasan, Erzam S., Muhammad Jahiding, and Jumiati Arsyad. "Analisis Proximate Dan Nilai Kalor Briket Hybrid (Brown Coal-Kulit Durian) Dengan Perekat Liquid Volatile Matter (Lvm) Yang Di Preparasi Dengan Metode Pirolisis." Jurnal Aplikasi Fisika 13, no. 1 (2017).

[31] Suryawan, I Wayan Koko, Sarwono, Ariyanti, Septiariva, Iva Yenis, \& Lee, Chun Hung. Evaluating Marine Debris Trends and the Potential of Incineration in the Context of the COVID-19 Pandemic in Southern Bali, Indonesia. Jurnal Ilmiah Perikanan dan Kelautan 13 (2021). https://doi.org/10.20473/iipk.v13i2.25164

[32] Qonitan, Fatimah Dinan, Suryawan, I. Wayan K., \& Rahman, Ari. Overview of Municipal Solid Waste Generation and Energy Utilization Potential in Major Cities of Indonesia. In Journal of Physics: Conference Series vol. 1858, no. 1, p. 012064. IOP Publishing, 2021. https://doi.org/10.1088/1742-6596/1858/1/012064

[33] Alsheyab, Mohammad AT, Daniel Schingnitz, Ali F. Al-Shawabkeh, and Sigrid Kusch. "Analysis of the potential use of major refuse-derived fuels in Jordan as supplementary fuel." Journal of the Air \& Waste Management Association 63, no. 8 (2013): 902-908. https://doi.org/10.1080/10962247.2013.776998 